\title{
Drones and the uninsurable security subjects
}

\author{
André Barrinha ${ }^{\mathrm{a}}$ and Sarah da Mota ${ }^{\mathrm{b}}$ \\ aSchool of Psychology, Politics and Sociology, Canterbury Christ Church University, Canterbury, Kent, UK; \\ ${ }^{b}$ Centro de Estudos Sociais, University of Coimbra, Coimbra, Portugal
}

\begin{abstract}
This paper engages with the security dynamics underlying the use of drones and their impact on security subjects - individuals and groups that are the ultimate recipients of specific security policies, regardless of whether these have beneficial effects on them. Using Mark Duffield's distinction between the insured Global North and the non-insured Global South, this paper discusses how drones generate a radical dissociation between the intervener and the intervened that ultimately produces new security environments at the margins of the international system. These new security environments are defined by the articulation between space, technologies and bodies: bodies of invisible subjects; bodies that are uninsurable.
\end{abstract}

\section{ARTICLE HISTORY}

Received 17 December 2015

Accepted 21 June 2016

\section{KEYWORDS}

Drones

US security policy counter-terrorism power uninsured subjects terrorism

"It is the perpetual dream of power to have its way without the visible exercise of will that would produce resistance"

James Der Derian ${ }^{1}$

\section{Introduction}

'Drones', more specifically Unmanned Aerial Vehicles (UAVs) and Unmanned Combat Air Vehicles (UCAVs), have, in the last few years, become a predominant term in the international relations' vocabulary. As technological instruments for surveillance, data collection and 'targeted killing', drones have become central to the counter-terrorism efforts of a number of countries, including Russia to Israel. ${ }^{2}$ However, no other country has made such intensive use of UAVs and UCAVs as the US in the last decade. Since 2001, the US Armed Forces and the Central intelligence Agency (CIA) have been using lethal drone strikes to disrupt and eliminate terrorist organisations such as Al-Qaeda and, more recently, the Islamic State (IS), implying that drone strikes could occur in countries other than those in which the US had a direct military engagement, as long as the presence of Al-Qaeda (or IS) affiliates could be verified. ${ }^{3}$ In the last decade, this practice increased its geographic scope, including countries such as Afghanistan, Iraq, Pakistan, Somalia and Yemen. ${ }^{4}$ The authority for drone strikes in Afghanistan derives from the Authorization for Use of Military Force (AUMF) passed by the US Congress shortly after $9 / 11$. The AUMF does not restrict in any way the use of military 
force against Al-Qaeda in Afghanistan, nor does it represent an endpoint to that power. ${ }^{5}$ Concerning the use of drones in other countries, Michael Boyle explains that since there is an assertion that the USA has the right to self-defence against Al-Qaeda under international law, the US has the legal arguments to expand drone operations against terrorist organisation in Pakistan, Yemen and Somalia. ${ }^{6}$ Moreover, these missions do not require the approval of Congress and their international legality is questionable. ${ }^{7}$ In 2013 , the US Administration changed their policy, restricting the use of drones in targeted killing operations but, as recently exemplified in the case of the two American citizens accidentally killed in an Al-Qaida compound, the information that is used to conduct these attacks is often highly incomplete or inaccurate. ${ }^{8}$ According to the data provided by the Bureau of Investigative Journalism, the US has totalised over 800 strikes in non-combat settings: Pakistan (2004-2016), Yemen (2002-2016), Somalia (2007-2016) and Afghanistan (2015-2016). If to this we add drone strikes, between 4946 and 7464 people have died in those countries as a result of US drone strikes. ${ }^{9}$ With the ongoing war against IS in Syria and Iraq, it is likely that numbers will grow significantly in the next year. ${ }^{10}$

The employment of drones as military weapons has raised multiple ethical questions, which have been profusely discussed in a literature that is mainly concerned with both the achievement of a just way of using technology in war contexts and the impact technology has on the nature of conflicts. ${ }^{11}$ They have also been questioned from a strategic standpoint: as former counterinsurgency advisor to Gen. David Petraeus, David Kilcullen and former US Army officer Andrew Exum argue in a widely discussed New York Times op-ed, the use of drones might ultimately produce opposite goals of counterinsurgency, generating resentment rather than winning the hearts and minds of local populations. ${ }^{12}$ This resonates with the views of a group of four former US Air Force drone operators - Brandon Bryant, Michael Haas, Stephen Lewis, and Cian Westmoreland - who have publicly spoken about their service, for the first time, in New York on 19 November 2015. They expressed that the killings end up aiding terrorist recruitment, namely among younger people eager of avenging unjust deaths by drone strikes. ${ }^{13}$ Said Brandon Bryant: 'We kill four and create ten [terrorists]' for 'If you kill someone's father or uncle or family member and they're not part of the problem, then all of a sudden these people want revenge.' ${ }^{14}$

Finally, the impact of killing by drones has also been felt at a deeper psychological level both by the local populations surviving drone strikes and by drone operators. ${ }^{15}$ This has been extensively documented in Living under Drones, a joint report by the International Human Rights and Conflict Resolution Clinic (Stanford Law School) and the Global Justice Clinic (NYU School of Law) from September 2012. ${ }^{16}$ Through a series of interviews conducted with drone strikes survivors, their families, witnesses, and local medical authorities among other relevant sources, the report clearly illustrates how the presence of drones terrorises a powerless population, and has given rise to (anticipatory) anxiety and psychological trauma. For survivors and witnesses, the symptoms are multiple: fear, post-traumatic stress disorder (PTSD), emotional breakdowns, loss of appetite, and sleep disturbances, among many others. ${ }^{17}$ As a result, not only have behaviours been affected, as social practices have been disrupted, habits broken. Children have ceased to go to school, and group gatherings for mourning, burials, tribal reunions have been avoided. Tahir Afzal, one of the report's interviewee, summarises: 
[Before, e]verybody was involved in their own labor work. We were all busy. But since the drone attacks have started, everybody is very scared and everybody is terrorized ... People are out of business, people are out of schools, because people are being killed by these drone attacks. ${ }^{18}$

As for the psychological impact on the drone operators, the normality of their life can be equally interrupted. A study published in 2013 by the US Armed Forces Health Surveillance Centre has found that drone pilots experience the same rate of mental health issues than pilots of manned aircraft. It suggests there is no significant difference in the rate of PTSD, depressive disorders, and anxiety disorders between the two kinds of pilots, as their risk profile is in fact similar, although drone pilots are said to face additional challenges such as lack of deployment rhythm, a lack of combat compartmentalisation, fatigue, sleep disorders, social isolation, and sedentary behaviour with prolonged screen time. ${ }^{19}$ In practice, of course, the consequences may be devastating. In the aforementioned group of four former drone operators and technicians, each of them has declared to suffer from some degree of PTSD: cocaine addiction, depression, recurrent nightmares, and suicidal thoughts. ${ }^{20}$

The use of drones evidently benefits from the now traditional perception that technology saves time, lives and enables progress in warfare. ${ }^{21}$ They do not convey physical risks for soldiers, whilst enabling the execution of missions in remote places, often inaccessible to ground forces. ${ }^{22}$ In that regard, they provide the intervening actor with a technical and strategic advantage in eliminating armed resistance. Drones are more than just 'new tools improving upon a long-standing practice' and, although they do have a potentially global reach, they are not globally deployed, at least as killing weapons; outside conflict contexts, they are utilised in the very margins of the international system; they are geographically selective weapons. ${ }^{23}$ Ultimately, drones reconfigure time and space as a new technology of intervention in the Global South; a technology that is based on an 'algorithm of racial distinction'. ${ }^{24}$ As argued by Jamie Allinson, they draw a dividing line between 'worthy lives' and a subjugated population unworthy of life and a priori destined to death. ${ }^{25}$

By focusing critically on the particular security dynamics underlying the use of drones and their impact on the security subjects - individuals and groups that are the recipients of specific security policies, regardless of whether or not they benefit from them - the article will offer a reflection on how drones operate as instruments of radical life and space differentiation between the margins of the Global South and the rest of the world. As it will be argued, drones produce a security subject who is, adapting Mark Duffield's terminology, fundamentally uninsurable. ${ }^{26}$ The use of these robots in killing operations announce the radicalisation of the distinction between the 'insured' in the Global North and the 'non-insured' in the Global South, via the exposure of the latter to the exclusive security concerns of the former. Drones play a productive role in the definition of new marginal spaces in the international system. For the inhabitants of these remote areas, not only is there no insurance mechanism, private or public, as they are part of a blurred other; guilty until proven the contrary, without a specific court on which to present their case or any other public institution to safeguard their existence.

Under these circumstances, the non-insured become uninsurable, a form of life that does not deserve specification or attention. This article's main contribution is to unpack how the use of drones symbolises the creation of a new type of subject in the Global South, highlighting how the exclusion from the benefits of the global liberal order can be constituted in different ways. The article will proceed in two parts. First, it will start by setting the conceptual tools framing the use of drones within an environment of fundamentally changed 
perceptions. Hence, issues of time and accuracy in the context of airspace sustain the notion that drones alter the spaces for security, meaning that they create new environments where both security and insecurity are produced. This ambiguous relationship may be understood as a radical dissociation between the lives of the subjects of security and the shrinking possibilities for secure spaces. Section two will approach in more depth the differentiation between these forms of 'insured' and 'non-insured' life, following Duffield's terminology. The practice of targeted killings by drones will be enhanced to show how uninsurable lives of security subjects are made immaterial, giving rise to the quest for the visibility of drone victims.

\section{Changing spaces of (in)security}

Technology has dramatically changed our perception of speed and time as announced by Paul Virilio's work on 'dromology' in the late 1970s:

Dromology originates from the Greek word, dromos. Hence, dromology is the science of the ride, the journey, the drive, the way. To me, this means that speed and riches are totally linked concepts. And that the history of the world is not only about the political economy of riches, that is, wealth, money, capital, but also about the political economy of speed. If time is money, as they say, then speed is power. ${ }^{27}$

According to Virilio, distances have shortened in terms of time, as has our relation to reality, namely through mobile phones, telecommunications media, cyberspace, video-conferencing, and air travel. ${ }^{28}$ The ability to move and to do things faster thus symbolises the power to apprehend and control reality differently, within a new relationship with time. As such, the conduct of warfare has been importantly influenced by the acceleration of information transmission - from pigeons, to the internet. ${ }^{29}$ Drawing on Foucault's panopticon as a model to an extra-terrestrial level of discipline and control, Virilio extends the dimensionality of Foucault's analysis by showing how the control of space has been force-multiplied by the control of pace. ${ }^{30}$ About the implications of this acceleration upon fear, self-preservation and the bodies, Virilio asserts:

In fact, the reduction of distances by the acceleration of movement is the effect of the instinct for self-preservation. Speed being simply the production of fear, it is flight and not the attack that prompts the violent distancing, the sudden burst of speed. ${ }^{31}$

Following this view, the use of drones effectively points to the apotheosis of an extra-territorial dimension of politics that is very much driven by issues of time, speed, accuracy and efficacy. Virilio's insights shed some light and structure to the conception of 'dissociation' in the context of drone warfare, to the extent that dissociation occurs at the level of perceptions. With drones, the real-time velocity of images corrupts the need for a longer-pace thinking/ decision-making of real-time effects on information, space, and on the materiality of the bodies. As Bryant states, 'It was just point ... and click'32 Stephen Lewis, another of the four former drone operators of the US Air Force to speak publicly about the topic, recalls on one occasion to be given an order to shoot a precise man in the following terms: 'One second he was there lying on the ground. The next second he was not there anymore.'33

Such compression of time and space leads to the potential creation of new environments. To Peter Adey, aeroplanes can produce 'environments' of war and terror, of imagined violence in a 'biopolitical management of the milieu.'34 This view is informed by his argument that a set of geographies, infra-structures, relations and processes connect air and land. Much 
inspired by the relational perspective found in Foucault, Adey really enhances how airspace produces important effects on both the 'aerial-body subject' and the population on the ground, or:

how the flesh and bones of the mobile body - at first so absent from the firework displays of 'Shock and Awe' in Iraq - that life of feelings, emotions, sensations and perceptions, has been fundamentally altered by the spaces and geometries of the aeroplane's movement. The aerial body is both the object and medium here. The conditions of its survival require that it is secured through all manner of techniques that, in turn, threaten the quality of that life. ${ }^{35}$

These conditions of overall velocity, which are magnified in the case of drones killing civilians, facilitate the political conditions of secrecy that occult the visibility and knowability of objects. ${ }^{36}$ In this sense, there is both a vertical relation between the aeroplane that is in the air, and a horizontal relation to the extent 'The aeroplane depends upon the geography of the earth for it to survive.. ${ }^{37}$ The idea of verticality is also depicted in Eyal Weizman's conception of a 'politics of verticality', which he claims is exercised by Israel in the context of its occupation of Gaza through the use of drones. ${ }^{38}$ This is a particular case, because the Oslo Accord significantly lowered the sovereign ceiling of the Palestinian state so as to include only architectural construction and low-flying helicopters. As a consequence, the upper layers remain in Israel's control. Weizman explains namely how the use of UAV's has facilitated even more this 'near absolute knowledge' of the Palestinian territory: 'Every floor in every house, every car, every telephone call or radio transmission, even the smallest event that occurs on the terrain, can thus be monitored, policed or destroyed from the air. ${ }^{39}$

Precision warfare imposes a vertical relation between the bodies of human subjects as well, in that it produces and reinvents bodies, recasts relations among bodies, it makes them intelligible and manipulable from the outside, from what Lauren Wilcox says is a 'vantage point of absolute power. 40

\section{Verticality and control (over life)}

The use of drones in the context of the war on terror produces a relation of vertical insecurity for the local subjects. Killing drones create an asymmetric relation, in which the intervener benefits from an absolute superiority by supposedly knowing who, where and when to attack the (supposedly) terrorists. On the one hand, this relation derives from a quite recent technological evolution that enables the use of drones in such contexts. Although remotely piloted vehicles have been in development since the Vietnam War, they have only been used for surveillance since the Gulf War (1990-1991), and been armed and used for assassination by the US since 2001 in Afghanistan. ${ }^{41}$ On the other hand, it corresponds to an older trend of 'risk-transfer', in which the risks of war and violence are transferred to the enemies and innocent civilians in war zones as a form of minimising casualties and life risks for the military. ${ }^{42}$

What is not acceptable is the existence of Western casualties, as in Western societies 'loss of life has become increasingly difficult to justify and ideas of sacrifice have waned.43 As 'safety' societies, 'permanently on the defensive', they opt for a modality of war that spares the life of their own soldiers, aiming at a legitimate and successful formula of a zero-deaths war for the Western nations intervening, whilst the deaths of the local civilian population may be countless. ${ }^{44}$ These dynamics became particularly visible after 9/11 when 'underdeveloped populations became a global concern'.45 Precision technology theoretically 
guarantees the accuracy in identifying and hitting targets - 'the missiles fired from drones can achieve a degree of accuracy that even satellite or laser guided munitions fired from aircraft would have difficulty in achieving. ${ }^{\prime 6}$ Politically, the apology of drone operations is sustained by a discourse of rationality in risk avoidance:

[o] ur actions are effective. Dozens of highly skilled core Al-Qaeda commanders, trainers, bomb makers, and operatives have been taken off the battlefield. Plots have been disrupted that would have targeted international aviation, US transit systems, European cities and our troops in Afghanistan. These strikes have saved lives. ${ }^{47}$

Furthermore, in contrast with the high degree of certainty and control of the political/governmental actors as expressed in the statement above, the individuals upon the territory under drone surveillance experience constant uncertainty, unpredictability, and insecurity of not knowing not only when and where, but also whether they might be taken for terrorists according to what they are doing. As experienced by the New York Times journalist David Rohde during his time as a hostage in Waziristan: '[t]he drones were terrifying. From the ground, it is impossible to determine who or what they are tracking as they circle overhead. The buzz of a distant propeller is a constant reminder of imminent death'.48

The underlying relation of power provides the intervener with the maintenance of privileges, whereby US security is upheld, both by fighting the risks of terrorism overseas, and by simultaneously avoiding US casualties. ${ }^{49}$ Ultimately, the use of drones in combating terrorism reveals a technique of power, practiced by the intervener on foreign ground over individuals, which is characterised by a distancing move away from human bodies and the risks they represent for the intervener.

Another important aspect of this radical dissociation consists in part of the altered notions of corporeality and spatiality. Tyler Wall and Torin Monahan approach this matter in terms of the non-differentiation of people: bodies become things to track, monitor, apprehend and kill. Entering data into a computer propagates the dehumanising abstraction, turning human bodies into spatial coordinates, or simply a 'bug splat. ${ }^{50}$ Drones thus normalise the on-going subjugation of individuals:'lumping together innocent civilians with enemy combatants, women and children with wanted terrorist leaders' without any particular regard for the political and social context..$^{51}$

According to Reprieve's report You Never Die Twice, death counts within the US Kill List are often inaccurate. The study found 41 names of men who had died multiple times in public reporting. Each assassination target died on average more than three times before their actual death. All of those failed strikes resulted in numerous civilian deaths, including many children. ${ }^{52}$ The section of the report entitled 'Who was killed instead?' appears as the most valuable interrogation, because it proceeds by showing the faces and the names of some of the innocent people targeted by drone strikes: the question that actually leads us to the problem of the name, of the designation of bodies, their personalisation and humanisation.

This discovery is not particularly surprising given the account of the aforementioned former US drone operators, who argued that they were inflicting 'heavy civilian casualties and have developed an institutional culture callous to the death of children and other innocents. ${ }^{53}$ Children appear on screens as 'smaller black shadows', and targeting them is often expressed in drone vocabulary as a way of 'cutting the grass before it grows too long', according to former US Air Force drone operator Michael Haas. ${ }^{54}$ 
Ultimately, following Grégoire Chamayou, we are witnessing a'redistribution of priorities: the yield from a policy designed to terrorise and eradicate now takes precedent over any consideration of its political effects on the population'.55 Unfortunately, assessing whether Pakistanis or Somalis living in the areas under constant drone surveillance should benefit from life insurance is a secondary and residual matter. What is ultimately at stake is that they powerlessly live in a space where the insurability of their lives is unlikely to be valued in the near future. Excluded from the process, and incapable of responding to the violence that results from that process, these subjects live in a context of uninsurability.

\section{Differentiated lives and uninsurability}

As argued thus far the use of drones has led to a radical differentiation between the 'insured' and the 'non-insured' life. ${ }^{56}$ In this section, we intend to further elaborate on this by developing the relation between uninsurability and the bodies of the security subjects.

For Mark Duffield, in the insured life, 'the contingencies of capitalist existence are ameliorated through risk-reducing and compensatory benefits funded through contributory social insurance, general taxation, private insurance and personal savings..57 The insured subject lives in the developed world, whereas the non-insured is part of the underdeveloped Global South. ${ }^{58}$ These two worlds are separated by a containment policy that 'functions as a global perimeter fence both separating and reproducing the generic life-chance divide between the developed and the underdeveloped worlds. ${ }^{59}$ Duffield's dichotomy in the context of the security-development nexus points towards a post-colonial positive biopolitical mechanism of social self-reliance. ${ }^{60}$ According to Mark Duffield, '[t] he generic difference between how developed-life and underdeveloped-life are supported or expected to live loosely defies the spatial geography of the global north and south.61 Whereas the insured life is characterised by 'its multiple dependencies and mass consumption', the non-insured life carries 'expectations of adaptive self-reliance within the confines of basic needs'. ${ }^{2}$ The non-insured are maintained within the context of a post-interventionist society in which war has given place to an 'expanding zone of international pacification' in which 'pacifying low-intensity insurgency is a long-term policing problem for the international community'.63

These zones of international pacification are no longer war zones, but areas where it is seen as legitimate to apply forms of external policing with the ultimate aim of guaranteeing the success of pre-defined security policies (usually under the shape of counter-terrorism). Such policing practices do not aim to provide security to the local populations, but rather to prevent security externalities against the interests of the intervening countries. The non-insured live in spaces where law does not apply in the same way; spaces normalised by these practices of radical differentiation in which targeted killings are seen 'as standard part of ongoing overseas contingency operations', whose consequences are often terrifying. ${ }^{64}$ These non-insured lives often inhabit in conflict or post-conflict settings; zones of pacification, where development and security sector reform policies operate hand in hand with counterinsurgency operations.

The use of drones for killing purposes creates a certain regime of truth in terms of the assessment made by the intervener on who is the 'other', the terrorist, the unlawful one, and who is not. In this context, drones produces a whole new security environment in which people are supposed to 'normally' go about their lives, while being in the same geographic 
areas in which the US conducts its personality and signature strikes. ${ }^{65}$ The latter in particular was supposed to have been phased out with Obama's policy change in 2013. However, '[n] early three years later, the administration has abandoned any pretence of reigning in its use of signature strikes' ${ }^{66}$

\section{Invisible bodies}

In October 2015, The Intercept disclosed a series of secret military documents in a collection called the 'Drone Papers'. These offer documentary evidence of a US Kill List, a covert programme that selects individual targets for assassination. ${ }^{67}$ In one of the Papers, authored by Cora Currier, the process by which the Obama administration has acted upon its 'list' in Yemen and Somalia is revealed. ${ }^{68}$ Accordingly, under US decisional process for drone strikes, President Obama only approves the targets, but not each individual strike. Although an overall count of strikes or deaths is not contained, it is noted that'relatively few high-level terrorists meet criteria for targeting. The same Drone Paper refers to numbers provided by the Bureau of Investigative Journalism to show that, although only 16 targets were authorised in Yemen, and four in Somalia by the end of June 2012, there were at least 54 drone strikes, killing a minimum of 293 people, including 55 civilians in Yemen; and at least three attacks, and minimum six people dead in Somalia. Besides, the CIA has reportedly created its own list and rules for strikes, which means there are additional strikes and deaths to those authorised by the Kill List that occur in the shadow. ${ }^{69}$

These facts and numbers lead to the need of discussing the ambiguity and controversy of the practice of targeting individuals. As argued by Kyle Grayson:

targeted killing and assassination can be seen as complex and potentially contradictory responses. On the one hand, they are the individualization of danger to the extreme, in that an existential threat to the species is located - at some moment in time - within the capabilities and/ or intentions of a single person. On the other hand, the act is not personal: the administrative decision to dispatch is not so much a result of 'who you are' as of 'what you are' or' what you have been determined to be' - an existential threat to the survival of the species. ${ }^{70}$

The decision to target an existential threat based on the assessment of 'intentions' or'patterns of life' may not be personal per se, but essential meanings are actually altered. To Wilcox, it makes the bodies to exist in 'dematerialized form, as images and information'71 A new meaning emerges that implies that the potential danger represented by the individual supplants who the individual actually is. In other words, the threat potential of the individuals overpowers the assessment made on his personality, corporeal presence, habits, attitudes, and acts. In practice, this becomes all the more controversial in the light of the reported targeting of groups of individuals based on the mere fact that many gathered bodies are judged suspect of terrorist activities. For instance, there have been accounts of follow-up attacks on people rescuing the injured of a previous drone strike, on mosques after the locals were exhorted to help civilians mistakenly hit, on mourners and funerals. ${ }^{72}$ This is also documented by the Stanford/NYU report regarding the impact of the constant exposure to indiscriminate drones in Pakistan on the willingness to rescue victims and provide medical assistance, on burial traditions and willingness to attend funerals, and other social, economic and cultural activities: '[t]here used to be funeral processions, lots of people used to participate ... But now, [the US has] even targeted funerals, they have targeted mosques, they have targeted 
people sitting together, so people are scared of everything, says Ibrahim Qasim in the report. $^{73}$

Therefore, put in broad terms, according to Michael Walzer, 'this isn't targeted killing', because

[i]f the targeted insurgent or terrorist leader is surrounded by, or simply in the vicinity of, a group of men who are, say, between the ages of fifteen and sixty (and even drone surveillance can't be precise about that), an attack is permitted, and everyone who is killed is counted as a legitimate target. ${ }^{74}$

This is also well illustrated by the case of drone strikes in Uruzgan, Afghanistan, where the Afghan military-aged males have been defined as a category of inherently dangerous people, leading to 'the assimilation of all members of that category to a threat that must be eliminated by death, and the further assimilation of all humans in sight of the drone to that category' ${ }^{75}$

With drones, different perceptual fields are at play. Although using drones implies an improved gaze of the environment and of the subjects on the ground for the operator, the imperativeness of time, speed, accuracy and efficacy makes drones to dematerialise the contexts they operate in, together with the bodies they destroy. This is to say that the immediate material perception enabled by sight largely overpowers the political and ethical perception of the human subjects:

[a]ny battlefield is above all a perceptual field, because the primary act is that of aiming, of attaining an objective. Once we have seen something, we have already started to destroy it. As long as something is invisible, it is protected by its invisibility. Whether it is arrows or stones people throw at each other, perception is the determining factor of war. ${ }^{76}$

Following Virilio's rationale, if drones enable the constant visibility of objects, they are making them vulnerable. Although drones are a material technique of power, because of the acceleration of the decisional processes implied by their use, they end up surpassing and making obsolete the materiality of bodies, together with their political dimension. Therefore, drones separate the human subject from his political and ethical importance. It is also in this ideational sense that drones make human bodies immaterial.

This dissociation of the human body from its political core has important consequences for the idea of life-valuation. The insured 'are entrenched within political imaginaries of protection, imaginaries that entail institutionalised ways of understanding what it means to promote and safeguard a way of life. ${ }^{77}$ However, that is not the case for Yemenis and Pakistanis living in the Federally Administered Tribal Areas, for their condition lies at the opposite spectrum of any system of life-valuation. That immateriality is reinforced by the US refusal to release information on the number of people killed in drone attacks. Although the illegality of US drone strikes was recognised for the first time by the High Court in Peshawar as a breach of Pakistan's national sovereignty in May 2013, the civilian deaths by drone strikes in those two countries hardly receive an official explanation or answer. ${ }^{78}$ As a result, the non-insured become uninsurable; they are made immaterial in a move that resembles Judith Butler's conception of the 'de-realisation of the Other':

What is real? Whose lives are real? How might reality be remade? Those who are unreal have, in a sense, already suffered the violence of de-realization. What, then, is the relation between violence and those lives considered as 'unreal'? Does violence effect that unreality? Does violence take place on the condition of that unreality? 
If violence is done against those who are unreal, then, from the perspective of violence, it fails to injure or negate those lives since those lives are already negated. But they have a strange way of remaining animated and so must be negated again (and again). They cannot be mourned because they are always already lost or, rather, stubbornly, in this state of deadness. Violence renews itself in the face of the apparent inexhaustibility of its object. The de-realization of the 'Other' means that it is neither alive nor dead, but interminably spectral. The infinite paranoia that imagines the war against terrorism as a war without end will be one that justifies itself endlessly in relation to the spectral infinity of its enemy. ${ }^{79}$

Influenced by Judith Butler, Lauren Wilcox defends a biopolitical reading of the 'bodies', which are essentially constituted to be managed and known in contemporary practices of violence and security. Regarding precision warfare and the use of drones more specifically, Wilcox conceives war as 'relationally and asymmetrically embodied in the figure of the posthuman, a figure that enables not only the destruction of bodies, but the production of those bodies as ungrievable, as bodies that never existed in the first place'.80 Wilcox's contribution crucially highlights the epistemological implications of how precision warfare makes civilian bodies 'unknowable', physically 'killable' and how the absence of body counts makes them also 'abject', 'unseen' and 'ungrievable' bodies. ${ }^{81}$ Once again, former drone operator of the US Air Force Michael Haas sustains this idea:

Ever step on ants and never give it another thought? That's what you are made to think of the targets - as just black blobs on a screen [...] You had to kill a part of your conscience to keep doing your job every day - and ignore those voices telling you this wasn't right. ${ }^{82}$

This 'detachment' and 'lack of empathy for human life' expressed by Haas are to work as facilitating factors to kill just 'terrorists' and not people. ${ }^{83}$

Here, the de-realisation of the Other is created by the inherent psychological distance between the drone operators and their human targets, who are only blurred images that detach them from human characteristics and reduce them to the status of possible terrorists. As argued by Grégoire Chamayou: '[w]arfare, from being possibly asymmetrical, becomes absolutely unilateral. ${ }^{84}$ The impossibility of response, the irrevocability of death, the negation of mourning, all concur to the de-politicisation of life and death in the context of the war on terror.

The reality of these invisible, uninsurable, bodies is also the reality of the new marginal spaces of the international system. These new spaces are not geographically bound, but they result from the articulation between space, body, and machine. Their marginality results from the combination of these three elements. Space, because they live in areas where they are already non-insurable: if they were living in the Global North, they would not run the risk of being targeted by a Predator or a Reaper. In the same vein, they are only uninsurable because that is made possible by the use of UCAVs. Technology grants their inexistence as individuals.

\section{Contesting invisibility}

As in any power relation, even those living in uninsurable lands have some margin for resistance. Uninsurability is not an entirely irreversible condition. In Pakistan, for instance, there is plenty of public awareness and contestation regarding the use of drones, which may be verified in the public manifestations claiming for the visibility of civilian bodies, because in many cases bodies disappear and are never to be found. One example is the '\#notabugsplat' initiative, an artistic manifestation set in a heavily bombed region of Pakistan, Khyber 
Pukhtoonkhwa, that is destined to be seen by Predator drone operators and satellites, to raise awareness of civilian casualties. ${ }^{85}$ Viewed from the sky, the art installation reflects the face of an innocent child victim.

Another is the story of Noor Behram told by Steve Coll. Behram is a Pakistani journalist who documents the drone attacks for the Foundation for Fundamental Rights, a Pakistani non-profit organisation that seeks redress for civilian casualties. Among other things, Behram has continuously photographed the sites of drone attacks to create a partial record of the dead, the wounded, and their detritus. ${ }^{86}$

These cases are clear evidences that Pakistani civilians essentially demand visibility, claiming for the 'realisation' of their bodies. These initiatives are clearly a 'petition for recognition', a solicitation for 'becoming, to instigate a transformation, to petition the future always in relation to the Other'; a petition for political recognition, or at least for some form of security. ${ }^{87}$

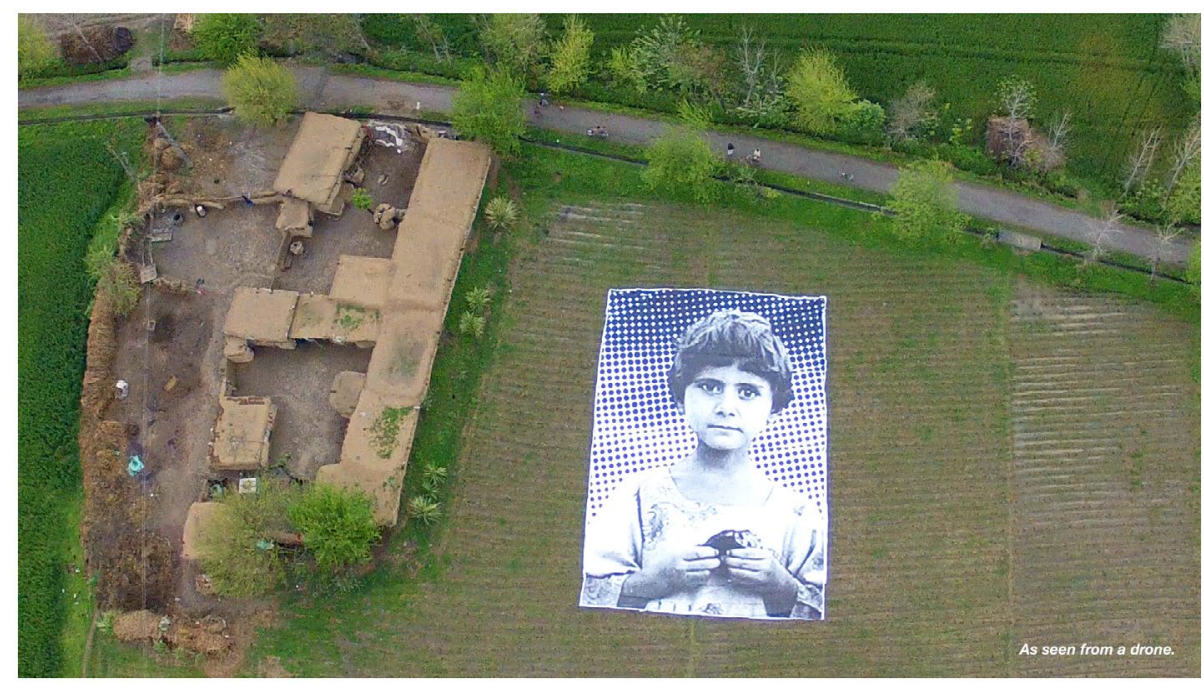

Figure 1. The face of an innocent child victim of drone strike, as seen from the sky. \#Notabugsplat\# initiative

\section{Conclusion}

This article attempted to broaden the understanding of the use of drones as a radical form of power. It was seen that drones express the idea of radicality by bringing into the field of security new interrelated perceptions of space, time and corporeality that originate new relations of power. These are translated into a situation of fundamental uninsurability for the security subjects.

Virilio's notions helped conceiving that drones may enhance the material dimension of the contexts drones operate in through magnified imaging, but that they also end up dematerialising the human subjects' political dimension, stripping them of further ethical consideration. By approaching the use of drones against terrorism, it was shown how their use allows the intervener to perpetuate its presence in the margins of the Global South. As described by Chamayou: 
[drones] inflict mass terror upon entire populations. It is this [...] that is the effect of permanent lethal surveillance: it amounts to a psychic imprisonment within a perimeter no longer defined by bars, barriers, and walls, but by the endless circling of flying watchtowers up above. ${ }^{88}$

Beyond the lives of the many innocent victims directly taken by drones, the negative contours of targeted killing have expanded to the lives of those who remain; both survivors and operators who do not always embody the interests of the intervener. By transferring the risk of death exclusively to the subject of security, drone strikes establish an asymmetric relation of superiority in favour of the intervener, thus revealing their power to alter the meanings of what lives are worth, of how they are valued.

This relation of domination consequently locates subjects outside the margins of the already non-insured life. They are underdeveloped life unmerited of being part of the security policies that are operationalised via Reapers and Predators that lethally control their skies. And this leads to a final and most concerning paradox: although boundless in terms of its potential use, the deployment of drones as killing weapons have in practice generated a new biopolitical frontier in world politics: that between the non-insured and the uninsured, thus radicalising the metaphorical distinction presented by Mark Duffield. In the final section of this paper it was seen how the uninsured are finding alternative forms of making their presence felt through art and social media; ways of making themselves visible and thus potentially insurable.

\section{Disclosure statement}

No potential conflict of interest was reported by the authors.

\section{Acknowledgements}

The authors would like to thank Munevver Cebeci, Sara Ramos Pinto, João Nunes and the participants at the 2nd Annual International Association for Peace and Conflict Studies at the University of Manchester (12-13 September 2013) and the Security and Technology section at the EISA PanEuropean Conference in Sicily (24-26 September 2015) for their helpful comments on earlier drafts of this paper. The authors also wish to thank Ali Rez and BBDO Pakistan for kindly permitting the reproduction of the \#Notabugsplat\# illustration in this article.

\section{Notes on Contributors}

André Barrinha is a Senior Lecturer in Politics and International Relations at Canterbury Christ Church University. He is also a Researcher at the Centre for Social Studies in Coimbra, Portugal. Before joining the Politics and International Relations team at Canterbury, André was a Visiting Assistant Professor in International Relations at the University of Coimbra. He holds a PhD in International Relations from the University of Kent. From 2004 to 2006 he worked at the Institute of Strategic and International Studies, Lisbon. His work focuses, primarily, on the intersection between political theory and security studies, with a particular focus on European security.

Sarah da Mota is a PhD Candidate in International Politics and Conflict Resolution at the University of Coimbra, currently writing her thesis on security and civilisation within NATO. 
Her main interests of investigation are critical security studies, political philosophy, international relations theory and history, US foreign policy and the Middle East.

\section{Notes}

1. In Der Derian, Cultural Practices in International Theory: Selected Essays, 50.

2. There is a wide variety of terms used to describe this tactic, eg preventive killings, active selfdefence, extrajudicial killings, interceptions, and named killings. However, the term 'targeted killing' has become the most broadly applied and accepted, according to Cullen, Role of Targeted Killing. To the Human Rights Council (HRC), targeted killing is an 'intentional, premeditated and deliberate use of lethal force' (par. 1), which may 'take place in a variety of contexts', and 'may be committed by governments and their agents in times of peace as well as armed conflict, or by organised armed groups in armed conflict' (par. 8). The means and methods include sniper fire, shooting at close range, missiles from helicopters, gunships, drones, the use of car bombs, and poison (par. 8). For the current paper, following Steven David in "Israel's policy of Target killing", targeted killing is used to refer to intentional slaying of a specific individual or group of individuals undertaken with explicit approval of governmental decision-makers.

3. Human Rights Council, Report of the Special Rapporteur; Williams, "The CIA's Covert Predator Drone War."

4. Blum and Heymann, "Law and Policy of Targeted Killing."

5. Anderson, "Targeted Killing and Drone Warfare"; Boyle, "Obama's Drone Wars."

6. Boyle, "Obama's Drone Wars."

7. O'Connell, "Unlawful Killing with Combat Drones"; Powers, "Sticks and Stones."

8. Ackerman et al., "White House Admits."

9. These numbers draw on the different countries' data presented on the website of The Bureau of Investigative Journalism, Drone War.

10. Schwartz, "One Year On."

11. See Anderson, "Targeted Killing and Drone Warfare"; Enemark, "Drones over Pakistan"; Hastings, "The Rise of Killer Drones"; Hudson et al., "Drone Warfare"; Statman, "Targeted Killings"; Strawser, Killing by Remote Control; Whetham, "Killer Drones."

12. From Kilcullen and Exum, "Death From Above, Outrage Down Below"; see also Kaag and Kreps, Drone Warfare.

13. From Murtaza, "Former Drone Operators Say."

14. From Gosztola, "You Can't Buy My Soul."

15. See the documentary Drone by Tonje Hessen Schei, 2014, for a visual example of this phenomenon.

16. International Human Rights. Living under Drones.

17. International Human Rights, Living under Drones, 82-83.

18. International Human Rights, Living under Drones, 149.

19. From Otto and Webber, "Mental Health Diagnoses and Counselling," 3.

20. There are different complementary press accounts of the public appearance of the four former US drone operators. See Pilkington, "Life as Drone Operator"; Gosztola, "You Can't Buy My Soul.” The testimony of Brandon Bryant in particular may be seen in Drone, Tony Schei's documentary.

21. Coker, War in an Age of Risk.

22. In the White House, "Fact Sheet" President Obama thus put it:'Despite our strong preference for the detention and prosecution of terrorists, sometimes this approach is foreclosed. Al-Qaeda and its affiliates try to gain a foothold in some of the most distant and unforgiving places on Earth. In this context, the United States has taken lethal, targeted action against Al-Qaeda and its associated forces, including with remotely piloted aircraft commonly referred to as drones'.

23. From Kaag and Kreps, Drone Warfare, 16. See also Berkowitz, "Drones and the Question," 160.

24. From Allinson, "The Necropolitics of Drones," 120; on the reconfiguration of time and space, see Adey, Aerial Life.

25. Allinson,"The Necropolitics of Drones," 119-120. 
26. Duffield, "Global Civil War."

27. Paul Virilio cited in Armitage, "From Modernism to Hypermodernism," 35. Virilio's 'dromology' was first developed in Negative Horizon.

28. Virilio, Negative Horizon; Virilio in Armitage, "From Modernism to Hypermodernism," 27.

29. Virilio in Armitage, "From Modernism to Hypermodernism," 36; Virilio, Negative Horizon, 153.

30. Der Derian, Cultural Practices in International Theory, 333.

31. From Virilio, Negative Horizon, 46.

32. From Schei, Drone.

33. From Gosztola, "You Can't Buy My Soul."

34. From Adey, Aerial Life, 149.

35. From Adey, Aerial Life, 206.

36. Walters, "Drone Strikes, Dingpolitik and Beyond," 103.

37. From Adey, Aerial Life, 5 .

38. Weizman, "The Politics of Verticality."

39. Ibid.

40. Wilcox, Bodies of Violence, 144-145.

41. From Medact, Drones, 3.

42. Shaw, "Risk-Transfer Militarism, Small Massacres"; Shaw, The New Western Way of War.

43. From Shaw, "Risk-Transfer Militarism, Small Massacres," 79.

44. From Beck, World at Risk, 153. See also Coker, War in an Age of Risk, 26.

45. From Evans, Liberal Terror, 59.

46. From Shea, "Precision Strike Capabilities," xvii; Shaw, "Risk-Transfer Militarism, Small Massacres," 248.

47. From The White House, "Fact Sheet."

48. Taken from Chamayou, Drone Theory, 44.

49. Foucault, Power, 344; Barrinha and da Vinha, "Dealing with Risk."

50. Wall and Monahan, "Surveillance and Violence from Afar," 246-247; Rogers and Hill, Unmanned, 81.

51. From Wall and Monahan, "Surveillance and Violence from Afar," 243.

52. Reprieve, You Never Die Twice.

53. From Murtaza, "Former Drone Operators Say."

54. From Pilkington, "Life as Drone Operator."

55. From Chamayou, Drone Theory, 70.

56. For a different reading of the insured/non-insured divide see Lobo-Guerrero, “The Capitalisation of'Excess Life."'

57. From Duffield, "Global Civil War," 150.

58. Duffield, Development, Security and Unending War; Duffield, "Global Civil War."

59. From Duffield, "Global Civil War," 147.

60. Duffield, Development, Security and Unending War.

61. From Duffield, "The Liberal Way of Development," 65.

62. Ibid., 65-66.

63. From Duffield, "Global Civil War," 159.

64. From Grayson, "The Ambivalence of Assassination," 26.

65. 'Personality strikes' consist in targeting individuals according to their role and function. It is known who they are and the strikes are approved to target them. 'Signature strikes' are much less specific, defined on 'profiles' based on behavioural patterns. These strikes can be conducted against unidentified individuals or groups of individuals who reveal certain defining characteristics related to terrorist activities or who are behaving in ways that only 'seem' suspicious. See International Human Rights, Living Under Drones. Also see, Hastings, "The Rise of Killer Drones."

66. de Luce and McLeary, "Obama's Most Dangerous Drone."

67. For further details on The Intercept, see www.theintercept.com

68. From Currier, "The Kill Chain."

69. Ibid.

70. From Grayson, “The Ambivalence of Assassination," 29. 
71. From Wilcox, Bodies of Violence, 157.

72. Woods and Lamb, "Drone Strikes in Pakistan."

73. International Human Rights, Living under Drones, 93-94.

74. Walzer, "Targeted Killing and Drone Warfare."

75. From Allinson, "The Necropolitics of Drones," 126.

76. From Virilio and Brügger, "Perception, Politics and the Intellectual," 85.

77. From Lobo-Guerrero, "The Capitalisation of 'Excess Life,"' 301.

78. About the Peshawar Court case, see Horowitz, and Rogers, "Case Watch." In Pakistan, there have been civilian initiatives to receive official explanations from local and US authorities. On this, see the activities led by Reprieve, a non-profit organisation that assists survivors and victims' families in their fight for legal accountability and justice ( www.reprieve.org). In Yemen as well the families of victims of drone attacks and airstrikes have inaugurated the National Organisation for Drone Victims (NODV), but this remains a particular and non-official initiative aiming at convincing the US government to stop the drone strikes. On this, see Al-Yarisi, "Drone Victims Organization Founded in Sana'a."

79. From Butler, Precarious Life, 33-34.

80. From Wilcox, Bodies of Violence, 132.

81. From Wilcox, Bodies of Violence, 136, 161-162.

82. From Pilkington, "Life as Drone Operator."

83. From Schei, Drone.

84. From Chamayou, Drone Theory, 13.

85. This initiative is mainly divulged online, on http://notabugsplat.com.

86. Coll, "The Unblinking Stare."

87. From Butler, Precarious Life, 44.

88. From Chamayou, Drone Theory, 45.

\section{Bibliography}

Ackerman, Spencer, Sabrina Siddiqui, and Paul Lewis. "White House Admits:We Didn't Know Who Drone Strike Was Aiming to Kill." The Guardian 23 April. 2015. https://www.theguardian.com/world/2015/ apr/23/drone-strike-al-qaida-targets-white-house

Adey, Peter. Aerial Life: Spaces, Mobilities, Affects. Malden, MA \& Oxford: Wiley-Blackwell, 2010.

Allinson, Jamie. “The Necropolitics of Drones." International Political Sociology 9 (2015): 113-127.

Al-Yarisi, Amal. “Drone Victims Organization Founded in Sana'a." Yemen times 3 April. 2014. Accessed July 30, 2015. http://www.yementimes.com/en/1769/news/3678/Drone-victims-organization-foundedin-Sana'a.htm

Anderson, Kenneth. "Targeted Killing and Drone Warfare: How We Came to Debate Whether There is a 'Legal Geography of War." The Social Science Research Network Electronic Paper Collection. Washington College of Law Research Paper No. 2011-16. 2011.

Armitage, John. "From Modernism to Hypermodernism and beyond: An Interview with Paul Virilio." Theory, Culture \& Society 16, no. 5-6 (1999): 25-55.

Barrinha, André, and Luis da Vinha. "Dealing with Risk: Precision Strikes and Interventionism in the Obama Administration." In Precision Strike Warfare and International Intervention, edited by Mike Aaronson, Wali Aslam, Tom Dyson, and Regina Rauxloh, 14-32. London: Routledge, 2015.

Beck, Ulrich. World at Risk. Cambridge: Polity Press, 2009.

Berkowitz, Roger. "Drones and the Question of 'the Human.' Ethics \& International Affairs 28, no. 2 (2014): 159-169.

Blum, Gabriella, and Philip Heymann. "Law and Policy of Targeted Killing." Harvard National Security Journal 145, no. 1 (2010): 145-170.

Boyle, Michael. "Obama's Drone Wars and the Normalisation of Extrajudicial Murder." The Guardian 11 June. 2012. https://www.theguardian.com/commentisfree/2012/jun/11/obama-drone-warsnormalisation-extrajudicial-killing

Butler, Judith. Precarious Life: The Powers of Mourning and Violence. London and New York: Verso, 2004. Chamayou, Grégoire. Drone Theory. Translated by Janet Lloyd. London: Penguin, 2015. 
Coker, Christopher. War in an Age of Risk. Cambridge: Polity Press, 2009.

Coll, Steve. "The Unblinking Stare:The Drone War in Pakistan." The New Yorker issue of "A reporter at large" 24 November. 2014. Accessed January 03, 2015. http://www.newyorker.com/magazine/2014/11/24/ unblinking-stare

Cullen, Peter. Role of Targeted Killing in the Campaign against Terror. Carlisle, PA: US Army War College, 2007.

Currier, Cora. "The Kill Chain." Article no 3 of the series "The Drone Papers", The Intercept 15 October. 2015. Accessed March 17, 2016. https://theintercept.com/drone-papers/

David, Steven. "Israel's policy of Target killing." Ethics and International Affairs 17, no. 1 (2003): 111-126.

De Luce, Dan, and Paul McLeary. "Obama's Most Dangerous Drone Tactic is Here to Stay." Foreign Policy 5 April. 2016. http://foreignpolicy.com/2016/04/05/obamas-most-dangerous-drone-tactic-is-hereto-stay/

Der Derian, James. Cultural Practices in International Theory: Selected Essays. London and New York: Routledge, 2009.

Duffield, Mark. Development Security and Unending War. Governing the World of Peoples. Cambridge: Polity Press, 2007.

Duffield, Mark. "Global Civil War:The Non-Insured, International Containment and Post-Interventionary Society." Journal of Refugee Studies 21, no. 2 (2008): 145-165.

Duffield, Mark. "The Liberal Way of Development and the Development-Security Impasse: Exploring the Global Life-Chance Divide." Security Dialogue 41, no. 1 (2010): 53-76.

Enemark, Christian. "Drones over Pakistan: Secrecy, Ethics, and Counterinsurgency." Asian Security 7 , no. 3 (2011): 218-237.

Evans, Brad. Liberal Terror. Cambridge: Polity Press, 2013.

Foucault, Michel. "Power: Essential Works of Michel Foucault 1954-1984.” edited by James D. Faubion, vol. 3. Transl. by Robert Hurley et. al. New York: New Press, 2000.

Gosztola, Kevin. "'You Can't Buy My Soul': Drone Whistleblowers Speak out." Shadowproof 19 November. 2015. Accessed April 5, 2016. https://shadowproof.com/2015/11/19/you-cant-buy-my-soul-dronewhistleblowers-speak-out/

Grayson, Kyle. "The Ambivalence of Assassination: Biopolitics, Culture and Political Violence." Security Dialogue 43, no. 1 (2012): 25-41.

Hastings, Michael. "The Rise of Killer Drones: How America Goes to War in Secret." Rolling Stone 26 April. 2012. http://www.rollingstone.com/politics/news/the-rise-of-the-killer-drones-how-america-goesto-war-in-secret-20120416

Horowitz, Jonathan, and Christopher Rogers. "Case Watch: A Court in Pakistan Addresses US Drone Attacks." Open Society Foundations 28 May. 2013. Accessed April 5, 2016. https://www. opensocietyfoundations.org/voices/case-watch-court-pakistan-addresses-us-drone-attacks

Hudson, Leila, Colin Owens, and Matt Flannes. “Drone Warfare: Blowback from the New American Way of War." Middle East Policy 18, no. 3 (2011): 122-132.

Human Rights Council (HRC). Report of the Special Rapporteur on Extrajudicial, Summary or Arbitrary Executions, Philip Alston. United Nations General Assembly, HRC 14th session, agenda item 3, 28 May, 2010.

International Human Rights and Conflict Resolution Clinic (Stanford Law School), and Global Justice Clinic (NYU School of Law). "Living under Drones: Death, Injury, and Trauma to Civilians from US Drone Practices in Pakistan." September 2012. Accessed April 5, 2016. http://chrgj.org/wp-content/ uploads/2012/10/Living-Under-Drones.pdf

Kaag, John, and Sarah Kreps. Drone Warfare. Cambridge: Polity Press, 2014.

Kilcullen, David, and Andrew McDonald Exum. "Death from above, Outrage down below." The New York times 16 May. 2009. Accessed September 20, 2015. http://www.nytimes.com/2009/05/17/ opinion/17exum.html?pagewanted=all\&_r=1

Lobo-Guerrero, Luis. "The Capitalisation of 'Excess Life' through Life Insurance." Global Society 28, no. 3 (2014): 300-316.

Medact. Drones: The Physical and Psychological Implications of a Global Theatre of War. London, 2012. www.medact.org

Murtaza, Hussain. "Former Drone Operators Say They Were'Horrified'by Cruelty of Assassination Program." The Intercept 19 November 2015. Accessed March 17, 2016. https://theintercept.com/2015/11/19/ former-drone-operators-say-they-were-horrified-by-cruelty-of-assassination-program/ 
O'Connell, Mary Ellen. "Unlawful Killing with Combat Drones. a Case Study of Pakistan, 2004-2009." Legal studies research paper, nº 09-43 (2010), Notre Dame Law School. Accessed March 15, 2015. http://ssrn.com/abstract=1501144

Otto, Jean L., and Bryant J. Webber. "Mental Health Diagnoses and Counseling among Pilots of Remotely Piloted Aircraft in the United States Air Force." Medical Surveillance Monthly Report 20, no. 3 (2013): 3-8.

Pilkington, Ed. “Life as Drone Operator: 'Ever Step on Ants and Never Give It Another Thought?"' The Guardian 19 November. 2015. Accessed April 5, 2016. http://www.theguardian.com/world/2015/ nov/18/life-as-a-drone-pilot-creech-air-force-base-nevada

Powers, Marina. "Sticks and Stones: The Relationship between Drone Strikes and Al-Qaeda's Portrayal of the United States." Critical Studies on Terrorism. Published online 22 October (2014): 1-11.

Reprieve. You Never Die Twice: Multiple Kills in the US Drone Program. 24 November. 2014. Accessed January 12, 2015. http://www.reprieve.org/us-drone-strikes-kill-28-unknown-people-for-everyintended-target-new-reprieve-report-reveals.html

Rogers, Ann, and John Hill. Unmanned. Drone Warfare and Global Security. London: Pluto Press, 2014. Schei, Tonje Hessen (director). Drone. Norway: Flimmer Film and Radiator Film, 2014.

Schwartz, Daniel. "One Year on, Drone Attacks against ISIS Increasing." CBC News 8 August. 2015. Accessed September 20, 2015. http://www.cbc.ca/news/world/one-year-on-drone-attacks-againstisis-increasing-1.3182002

Shaw, Martin. "Risk-Transfer Militarism, Small Massacres and the Historic Legitimacy of War." International Relations 16, no. 3 (2002): 343-359.

Shaw, Martin. The New Western Way of War. Cambridge \& Malden: Polity Press, 2005.

Shea, Jamie. "Precision Strike Capabilities: Political and Strategic Consequence." In Precision Strike Warfare and International Intervention, edited by Mike Aaronson, Wali Aslam, Tom Dyson, and Regina Rauxloh, xvi-xxiv. London: Routledge, 2015.

Statman, Daniel. “Targeted Killings.” Theoretical Inquiries in Law 5, no. 1 (2008): 179-198.

Strawser, Bradley Jay. Killing by Remote Control: The Ethics of an Unmanned Military. Foreword by Jeff McMahan. Oxford: Oxford University Press, 2013.

The Bureau of Investigative Journalism. Drone War 2015. Accessed September 2, 2015. https://www. thebureauinvestigates.com/category/projects/drones

The White House. Fact Sheet: The President's May 23 Speech on Counterterrorism." Office of the Press Secretary, 23 May 2013. Accessed July 16, 2015. https://www.whitehouse.gov/the-pressoffice/2013/05/23/fact-sheet-president-s-may-23-speech-counterterrorism

Virilio, Paul. Negative Horizon. an Essay in Dromoscopy. Translated. by Michael Degener. London and New York: Continuum, 2005(1984).

Virilio, Paul, and Niels Brügger. "Perception, Politics and the Intellectual. Interview with Niels Brügger." In Virilio Live: Selected Interviews, edited by John Armitage, 82-96. London, Thousand Oaks, New Delhi: Sage Publications, 2001.

Wall, Tyler, and Torin Monahan. "Surveillance and Violence from Afar: The Politics of Drones and Liminal Security-Scapes." Theoretical Criminology 15, no. 3 (2011): 239-254.

Walters, William. "Drone Strikes, Dingpolitik and beyond: Furthering the Debate on Materiality and Security." Security Dialogue 45, no. 2 (2014): 101-118.

Walzer, Michael. “Targeted Killing and Drone Warfare." Dissent 11 January. 2013. Accessed March 15, 2016. https://www.dissentmagazine.org/online_articles/targeted-killing-and-drone-warfare

Weizman, Eyal. "The Politics of Verticality.” Open Democracy, 2 May 2002. 2002. Accessed April 5, 2016. https://www.opendemocracy.net/conflict-politicsverticality/article_810.jsp

Whetham, David. "Killer Drones." The RUSI Journal 158, no. 3 (2013): 22-32.

Wilcox, Lauren B. Bodies of Violence: Theorizing Embodied Subjects in International Relations. New York: Oxford University Press, 2015.

Williams, Brian G. "The CIA's Covert Predator Drone War in Pakistan, 2004-2010: The History of an Assassination Campaign." Studies in Conflict \& Terrorism 33, no. 10 (2010): 871-892.

Woods, Chris, and Christina Lamb. “Drone Strikes in Pakistan. CIA Tactics in Pakistan Include Targeting Rescuers and Funerals." The Bureau of Investigative Journalism 4 February. 2012. Accessed April 5, 2016. https://www.thebureauinvestigates.com/2012/02/04/obama-terror-drones-cia-tactics-inpakistan-include-targeting-rescuers-and-funerals/ 